\title{
Effect of Ecological Practices Adoption on Environmental Performance of Selected SMEs in Karnataka
}

\author{
Prakash Thyagaraj Rajeshwari, Byrappa Harani* $^{*}$ \\ School of Commerce, Reva University, Bangalore, India \\ Email: charvi.pt@gmail.com, *harani.b@reva.edu.in
}

How to cite this paper: Rajeshwari, P. T., \& Harani, B. (2021). Effect of Ecological Practices Adoption on Environmental Performance of Selected SMEs in Karnataka. Open Journal of Business and Management, 9, 2152-2170.

https://doi.org/10.4236/ojbm.2021.95114

Received: June 19, 2021

Accepted: August 20, 2021

Published: August 23, 2021

Copyright $\odot 2021$ by author(s) and Scientific Research Publishing Inc. This work is licensed under the Creative Commons Attribution International License (CC BY 4.0).

http://creativecommons.org/licenses/by/4.0/

(c) (i) Open Access

\begin{abstract}
Environmental challenges and problems in the new sector have been growing increasingly. This has contributed to the development of small and medium-sized businesses focused on environmental issues and green technologies. However, in addition to focusing on producing more green products, firms should also focus on how to manage them. The implementation of Ecological Activities is an effective method for an organisation to manage its environmental concerns and enhance its environmental efficiency. This study examines the impact of the ecological practises of small and medium-sized enterprises (SMEs) in Karnataka. It also identifies effective ecological practises adopted by selected small and medium-sized enterprises. Quantitative data were obtained through a survey of 118 small and medium-sized manufacturing enterprises located in the entire Mysore and Bengaluru area. Review of the results has shown that there is an optimistic rate of sustainable environmental practise among small and medium-sized businesses, with enhancement of green purchasing as a top priority, followed by waste reduction and recycling. The outcome has also demonstrated that energy efficiency is not greatly influenced by environmental practises. Based on the outcome, the conclusions of this research provide new pathways for the future research. It can be inferred that the introduction of sustainable practises is a method for small and medium-sized businesses to control and solve environmental problems and enhance environmental performance. Limitations and suggestions for future study are also discussed.
\end{abstract}

\section{Keywords}

Ecological Practices, Environmental Performance, SMEs 


\section{Introduction}

As industrialisation grew, the quantity of non-biodegradable or even hazardous compounds in the waste material increased. Bengaluru alone is estimated to generate approximately 125 tons of e-waste per year, which is projected to increase to 147 tonnes per annum in 2020

http://karenvis.nic.in/Database/WasteManagement_7899.aspx?format=Print and Plastic usage in the city is roughly $16 \mathrm{~kg}$ per person per month https://economictimes.indiatimes.com/news/politics-and-nation/plastic-waste-i n-bengaluru-bbmp-hasiru-dala-undp-set-for-a-pact/articleshow/65960038.cms. Thus many SMEs in Bengaluru operate in small sheds and have insufficient space to set up hazardous waste storage facilities, and generate relatively modest quantities of hazardous waste

https://www.thehindubusinessline.com/economy/Karnataka-Pollution-ControlBoard-to-collect-hazardous-waste-from-industries/article20562855.ece\#. As in other parts of the India, the efficiency of waste management in the urban areas of Karnataka has been very poor and weak. Many major cities view inadequately managed and unregulated waste collection schemes with weak, even non-existent facilities. The country's 13 states (Maharashtra, Gujarat, Tamil Nadu, Orissa, Madhya Pradesh, Assam, Uttar Pradesh, West Bengal, Kerala, Andhra Pradesh, Telangana, Karnataka, and Rajasthan) account for 97 per cent of total hazardous waste generations. Maharashtra, Gujarat, Andhra Pradesh, Telangana and Tamil $\mathrm{Nadu}$ are the top five waste-generating States. On the other hand, states like Himachal Pradesh, Jammu \& Kashmir generate less than 20,000 million tonnes per annum for all the North Eastern states except Assam (Murali Krishna, 2015). Waste management is a chronic challenge for city/town officials and is struggling due to inadequate systems, insufficient resources, persistent resource development and increasing urbanisation. Obstacles and handicaps, along with a lack of knowledge of the multiple factors that contribute to a decline in waste, have an impact on waste management. The quantity of hazardous waste has not been documented in developing countries, as these waste streams are managed incorrectly and therefore have greater environmental impacts than reported. It is not an easy job to determine exact quantities of toxic substances (Gu et al., 2014). Consequently, this waste stream can end up being combined with general domestic or industrial, or disposed of by burning, burying, or discharging to sewage water, or ground surface in an irresponsible manner. There are currently minimal options in industrialized countries for toxic waste sources to handle it properly (Lu et al., 2013). The issue of waste disposal is also exacerbated by the lack of a collective human mind-set, which is unwilling and unable to devote its pest to the cause of waste management and leaves all responsibility to the civil authorities. In comparison, the implementation of environmental regulations is yet to affect the Karnataka ecology. Regional authorities are reluctant to fix problems relating to the prevention of pollution, waste management and envi- 
ronmental conservation in some areas of the state. Hazardous waste, industrial waste, medical waste, plastic waste, e-waste and pharmaceutical waste, etc. are the categories of waste accountable for environmental contamination https://www.karnataka.gov.in/empri/Documents/Waste\%20Management-final.p df.

SMEs are the backbone of the economy and play a rapidly growing role in the industrial sector (Seema et al., 2016). SMEs contribute 45 per cent of overall manufacturing output

https://www.thehindubusinessline.com/economy/Karnataka-Pollution-ControlBoard-to-collect-hazardous-waste-from\%20industries/article20562855.ece\#\%20 msme.gov.in/KPMG/CRISIL/CII. According to the Department of Commerce and Industry survey, there are 43,000 SMEs in Karnataka. The manufacturing fields were divided into four colour groups. In the current categorization scheme, the category Red is a heavy-polluting industry, the category Orange is a moderately polluting industry, the category Green is a substantially low-polluting industry and the category White is non-polluting. At the global level, especially in India, the ecological role of the industries responsible for their sustainable business practises is becoming increasingly visible. In a nation like India, managing both natural capital and the ecosystem has become incredibly valuable. Any company feels the value of managing sustainable development. But the global understanding and knowledge of environmental significance has nurtured the development of a new business sector known as "Ecological Management/Environmental Management." The environmental protection system is an essential aspect of the environmental management structure. In the background of a sustainable global economy, there is no modern experience of the destructive effect of human business activities on the environment. Environmental contamination in India is now a significant problem and considerable efforts are being made to protect the environment (Pradip, 2016). Environmentally conscious represents the social understanding of saving and supporting the natural wealth of the World, maintaining and protecting them for the sake of civilisation. As consumers grow more mindful of environmental concerns, demand for organic goods is growing. This increased knowledge and attention of environmental issues puts certain pressures on company functions to become greener. The goal of this analysis is to recognise the most common environmental practises implemented by SMEs and their effects on environmental performance. The results of this study are believed to be useful for SMEs to achieve a deeper understanding between the implementation of sustainable policies and their effect on the ecological competence of SMEs.

\section{Review of Literature}

This segment discusses the sustainable policies of SMEs and their relationship to environmental quality. Different subsections of the literature review are orga- 
nised. The first applies to the concept and details of sustainable standards for SMEs and the next section addresses the impact of environmental practises on environmental performance. These sections would offer a better description of the concept behind the title.

\subsection{Ecological Practices}

Ecological Practices is a political consciousness that encourages the conservation of natural resources by organizations, the optimal utilisation of energy reserves within the context of an institutional definition and environmentally sound application (Goyal, 2013). Agan et al. (2013) have described state rules and regulations; consumers, internal benefits and firm productivity are the driving force behind Ecological Activities. Tseng et al. (2016) indicates that the removal of waste and emissions at source would increase the environmental and environmental performance of the company. Paula et al. (2014) indicated that sustainable activities, including green procurement, green production, materials management, green distribution/marketing and reverse logistics, contribute to the role of environmental consciousness in green initiatives, from raw material extraction to product line, manufacturing techniques and final product distribution to the consumer. "Eco-efficiency" is the most critical component of sustainable progress for SMEs (Cote et al., 2016). The purpose of this paper is to investigate the circumstances and contexts surrounding three environmental practices adopted in SMEs, namely green purchasing, waste reduction and recycling and energy efficiency. Ecological activities are laid out in Table 1 providing an analytical context.

\subsection{SMEs and Ecological Practices}

Small to medium-sized businesses prefer to be individualistic regarding the impact of owners. Studies have shown that few external agencies, other than regulatory/legislative bodies, are exerting pressure on SMEs to move beyond their "just compliance" positions on green policies (Vernon et al., 2013). Lepoutre and Heene (2016) say that this is due to the relative lack of "visibility" of small and medium-sized businesses compared to large companies. The less transparent an enterprise is, the less vulnerable it is to the public's scrutiny and, as a result, the more stretched it is to that quarter. The authors add that a SME might wish to become more visible (i.e. given its size) on the basis of its community history and reap the advantage of enhanced market reputation by being, in any case, a "green leader." Growing consumer awareness (or "eco-consciousness") has been believed to drive environmental progress in certain small and medium-sized businesses. Indeed, several surveys have suggested that there are opportunities for strategic promotion, business development and competitive advantage for small and medium-sized enterprises by promoting environmental innovation and transparency (Cote et al., 2016). 
Table 1. Showing items of ecological practices in SMEs.

\begin{tabular}{|c|c|c|c|}
\hline $\begin{array}{c}\text { Variables (Ecological } \\
\text { Practices) }\end{array}$ & Description & Source & $\begin{array}{l}\text { Items taken } \\
\text { for research }\end{array}$ \\
\hline $\begin{array}{c}\text { Green } \\
\text { Purchasing }\end{array}$ & $\begin{array}{l}\text { Eltayeb et al. (2011) describe green purchasing } \\
\text { as an environmentally focused purchasing } \\
\text { practise focusing on the procurement of goods } \\
\text { or materials that satisfy environmental concerns } \\
\text { in terms of waste disposal, promotion of reuse, } \\
\text { recycle, resource reduction, and material } \\
\text { replacement. }\end{array}$ & $\begin{array}{l}\text { When making buying decisions, consider } \\
\text { environmental factors; Green (recyclable, recycled, } \\
\text { non-toxic, biodegradable) items, goods and } \\
\text { services should be purchased; There was no } \\
\text { eco-friendly packaging used after that; Preferred } \\
\text { vendors if ISO } 14001 \text { certification is obtained. }\end{array}$ & $\begin{array}{l}\text { (Montabon et al., } \\
\text { 2017), (Eltayeb et al., } \\
\text { 2011) }\end{array}$ \\
\hline $\begin{array}{c}\text { Energy } \\
\text { Efficiency and } \\
\text { Energy Conservation }\end{array}$ & $\begin{array}{l}\text { Energy efficiency and conservation are the most } \\
\text { visible aspects introduced, handled, and } \\
\text { regulated in industrial firms to reduce potential } \\
\text { negative environmental effects and increase the } \\
\text { company's image. The primary goal is to } \\
\text { minimise the amount of water used; thus, } \\
\text { methods and processes for water purification, } \\
\text { recycling, and reusing should be investigated in } \\
\text { order to achieve sustainability and viability in } \\
\text { the long run. }\end{array}$ & $\begin{array}{l}\text { Substituting mechanised processes for manual } \\
\text { labour; Processes that remove or reduce electricity } \\
\text { consumption should be chosen; Built equipment } \\
\text { to keep energy consumption at a minimum; The } \\
\text { installed equipment to avoid energy waste and } \\
\text { leaks is inadequate; Placing in more } \\
\text { energy-efficient lighting; Conserve electricity by } \\
\text { turning off lights where there is enough natural } \\
\text { light; Turning off appliances, air conditioning, and } \\
\text { computers as they are the last to leave/are not in } \\
\text { service. }\end{array}$ & $\begin{array}{c}\text { (Peter et al., 2017), } \\
\text { (Ghazilla et al., 2015) }\end{array}$ \\
\hline $\begin{array}{l}\text { Waste } \\
\text { Reduction } \\
\text { and } \\
\text { Recycling }\end{array}$ & $\begin{array}{l}\text { A waste management policy is a vital method for } \\
\text { reducing the use of natural resources, managing } \\
\text { waste effectively, and sustaining green practises. } \\
\text { Waste reduction, which is one part of } \\
\text { sustainable green practises, contributes to } \\
\text { increased efficiency in SMEs while still } \\
\text { protecting the ecosystem. }\end{array}$ & $\begin{array}{l}\text { The company understands waste management and } \\
\text { recycling; Employees' knowledge of waste disposal } \\
\text { and recycling is not at the expected stage; There is } \\
\text { no clear design for minimising waste and reusing } \\
\text { or recycling as much as possible; Employees are } \\
\text { being trained in waste management by the } \\
\text { company; Adoption of environmentally friendly } \\
\text { waste collection and recycling procedures; }\end{array}$ & (Peter et al., 2017) \\
\hline
\end{tabular}

\subsection{Effect of Ecological Practices on Environmental Performance and Hypothesis Development}

Environmental performance is commonly concerned with saving energy and reducing waste, congestion and emissions (Shivani \& Jain, 2017). There are relatively few studies exploring the relationship between ecological activities and environmental efficiency. The positive correlation between the adoption of environmental policies and environmental success has the potential to promote the embrace of environmental practises as a method to improve business performance (Geng et al., 2017). Environmental performance is typically based on saving money and reducing waste, degradation and emissions. In addition, linking green management practises with the manufacturing sectors included mitigating air emissions, wastewater and solid waste as well as reducing the use of hazardous materials (Shivani \& Jain, 2017). Environmental success assessments included metrics for energy savings and waste avoidance, environmental degradation and pollution (Chiou et al., 2011; Lee et al., 2015). The study shows an increasing beneficial correlation between ecological practises and environmental performance in the manufacturing sector. From this point of view, it has been seen that significant environmental efficiency can be accomplished by eliminat- 
ing waste.

Zhu et al. (2007) indicated that environmental management operations would have a complete and substantial impact on environmental efficiency, while green procurement would have detrimental consequences on environmental performance and the remaining practises would have no impact. On the opposite, Laosirihongthong et al. (2013) found that green procurement has an absolute effect on environmental efficiency and is the only relevant activity. Green Jr. et al. (2012) found that green purchasing does not have a significant effect; however, energy conservation, investment recovery and customer cooperation have a significant impact on environmental efficiency. Based on the topic referred to above, there are few beneficial effects of the introduction of sustainable practises on environmental efficiency mentioned in Table 2 . The most recent research attempted to examine the effect of environmental practises on environmental results, focusing on the mixed findings of previous studies. The following hypothesis has been proposed on the basis of the aforementioned discussion:

H1: Green purchasing has a significant impact on environmental performance;

$\mathrm{H} 2$ : Energy efficiency has a significant impact on environmental performance;

$\mathrm{H} 3$ : Waste reduction and recycling have a significant impact on environmental performance.

A regression test was used to classify linear relationships between independent variables (ecological practises, including green purchasing, energy efficiency and waste reduction and recycling) and dependent variables (environmental performance) as hypothesised from $\mathrm{H} 1$ to $\mathrm{H} 3$.

\subsection{Research Gap}

Empirical research on ecological practises is incomplete and has not been given priority in previous studies. Investigations into the effects of environmental practises on environmental efficiency in the sense of small and medium-sized businesses are very minimal. The author thus aims to address this vacuum by concentrating on the environmental practises of small and medium-sized businesses.

\subsection{Statement of Problem}

In today's global market environment, SMEs face intensified economic, regulatory

Table 2. Showing items of environmental performance.

\begin{tabular}{|c|c|c|c|}
\hline Variable & Description & Items taken for research & Source \\
\hline $\begin{array}{l}\text { Environmental } \\
\text { Performance }\end{array}$ & $\begin{array}{l}\text { Environmental performance is } \\
\text { typically concerned with energy } \\
\text { conservation and the reduction of } \\
\text { waste, contamination, and carbon. }\end{array}$ & $\begin{array}{l}\text { Waste, groundwater, and solid waste reduction; Quality } \\
\text { technology tools; Reduced use of toxic chemicals; } \\
\text { Increased employee understanding of the importance of } \\
\text { conserving natural resources; Reduced effluent and } \\
\text { pollution levels due to recycling and reuse. }\end{array}$ & $\begin{array}{c}\text { Geng et al. (2017), } \\
\text { Shivani \& Jain (2017), } \\
\text { Chardine-Baumann et al. } \\
\text { (2014) }\end{array}$ \\
\hline
\end{tabular}


and societal burdens. There is also pressure on environmental sustainability, which has to be put in place policies to reduce the impact of goods and services on the environment. In reality, however, industrial firms are significantly degrading the atmosphere and the environment, with inevitable consequences, considering the immense volume of unrecyclable materials consumed.

\section{Research Methodology}

The following section addresses the testing framework, consisting of design of questionnaire, respondents and data collection methods, sample selection and interpretation techniques.

\subsection{Designing Questionnaire}

To examine the influence of ecological practises on environmental performance, a self-administered questionnaire was designed. Based on a review of the literature, a structured questionnaire was constructed with three core constructs: green purchasing, energy efficiency, waste reduction, and recycling, and one dependent construct: environmental performance (Table 1 and Table 2). All variables were evaluated on a five-point scale ranging from "strongly agree" to "strongly disagree." In order to attain the aims of the study, Section A of the questionnaire entitled "Demographic Profile" includes 8 chosen demographic questions from the researcher. Section B, entitled "Ecological Practices," includes three parameter ecological practises, including "green purchasing", "energy efficiency" and "waste reduction and recycling". Finally, the dependent variable called "Environmental Performance" in the section C containing eleven questions.

\subsection{Respondents and Data Collection}

Data was obtained using questionnaire surveys from owners/managers of small and medium-sized manufacturing firms in Karnataka. The overall sample size is 170 , of which only 118 were available, resulting in a response rate of about 74 per cent by electronic mail and door-to-door physical surveys. This paper also uses secondary knowledge obtained from thesis, peer-reviewed journals and papers on the subject.

\subsection{Sample Selection}

The data used were collected from questionnaires, responses from small and medium-sized manufacturing firms in the Mysore and Bangalore regions of Karnataka. Stratified random sampling, one of the methods of probability sampling, favoured data collection. Small and medium-sized manufacturing companies selected from the database of Department of Commerce and Industry, which covers the electrical and electronic industries, the pharmaceutical industry, the chemical industry and the plastics industry. 


\subsection{Analysis Technique}

To validate the hypothesis of this analysis, the statistical programme SPSS (Statistic Product and Service Solutions) was used to quantify and analyse quantitative data. Several methods were used for analysis, including descriptive, factor analysis, correlation and regression. Descriptive analysis can help to illustrate the tendency of small and medium-sized enterprises (SMEs) producers to follow ecological practises, and standard deviations indicate how much difference is there between these practises. Factor analysis has helped to validate the groupings used in this research. Factors loadings were obtained using the main component analysis followed by a varimax rotation using the Kaiser Normalization Rotation Technique. The Pearson correlation coefficient was calculated to measure the degree to which the variables were related. The results of Pearson's coefficient of association vary from -1 to 1 . Regression analysis was adopted to examine the impact of ecological practices implementation on environmental performance.

\section{Data Analysis and Results}

\subsection{Descriptive Analysis}

Table 3 shows the demographics of the firms' surveyed. The sample consisted of 59.5 per cent small and 40.5 per cent medium-sized businesses and most of the

Table 3. Showing the sample firms' demographics.

\begin{tabular}{|c|c|c|c|}
\hline Variable & Category & $\mathbf{N}$ & Rate (\%) \\
\hline \multirow{2}{*}{ Industry type } & Small Scale Industry & 70 & 59.5 \\
\hline & Medium Scale Industry & 48 & 40.5 \\
\hline \multirow{2}{*}{ Occupied position } & Owner & 34 & 29.1 \\
\hline & Manager & 84 & 71.1 \\
\hline \multirow{4}{*}{$\begin{array}{l}\text { Years of firm } \\
\text { established }\end{array}$} & Below 5 years & 25 & 21.4 \\
\hline & 5 to 10 years & 34 & 28.9 \\
\hline & 10 to 15 years & 24 & 20.1 \\
\hline & Over 15 years & 35 & 29.6 \\
\hline \multirow{4}{*}{ Business nature } & electrical and electronic devices & 35 & 29.6 \\
\hline & pharmaceutical products & 34 & 28.6 \\
\hline & chemical products & 36 & 30.2 \\
\hline & plastic products & 13 & 11.6 \\
\hline \multirow{3}{*}{ ISO certification } & ISO certified & 62 & 52.8 \\
\hline & Preparing to implement ISO & 40 & 33.9 \\
\hline & Not ISO certified & 16 & 13.3 \\
\hline
\end{tabular}

Note: " $\mathrm{N}$ " is the total frequency of all respondents. "Rate" in percent denotes the frequency divided by the total number of the valid response. 
respondents were managers (71.1 per cent) and owners (29.1 percent). Almost 29.6 percent of SMEs are over 15 years of age, followed by 28.9 percent between 5 and 10 years of age, 21.4 percent below 5 years of age and 20.1 percent between 10 and 15 years of age. Small and medium-sized companies (SMEs) were producers of electrical and electronic devices (29.6 per cent), pharmaceutical products (28.6 per cent), chemical products (30.2 per cent) and plastic products (11.6 percent). As far as ISO 14001 accreditation is concerned, it is clear that $52.8 \%$ of SMEs are ISO-certified, $33.9 \%$ are preparing to implement and $13.3 \%$ are not ISO 14001-certified.

Table 4 demonstrates the magnitude of findings derived from the descriptive study of the implementation practises of ecological initiatives. Generally, all

Table 4. Showing extent and differences in the ecological practices in SMEs.

\begin{tabular}{|c|c|c|c|c|}
\hline Ecological Practices & Minimum & Maximum & Mean & Std. Deviation \\
\hline \multicolumn{5}{|l|}{ Green Purchasing } \\
\hline $\begin{array}{l}\text { Apply environmental criteria when making } \\
\text { purchasing decisions. }\end{array}$ & 1 & 5 & 4.56 & 1.065 \\
\hline Purchase Green & 1 & 5 & 4.44 & 1.122 \\
\hline Eco friendly packaging & 1 & 5 & 4.12 & 1.226 \\
\hline Preferred suppliers if ISO 14001 certification. & 1 & 5 & 4.51 & 1.018 \\
\hline \multicolumn{5}{|l|}{ Energy efficiency } \\
\hline $\begin{array}{l}\text { Replacing manual efforts with alternate mechanized } \\
\text { operations. }\end{array}$ & 1 & 5 & 3.90 & 1.109 \\
\hline $\begin{array}{l}\text { Select processes that eliminate or reduce energy } \\
\text { consumption. }\end{array}$ & 1 & 5 & 3.19 & 1.016 \\
\hline $\begin{array}{l}\text { Equipment installed to keep the energy } \\
\text { consumption level at the optimum }\end{array}$ & 1 & 5 & 4.45 & 1.142 \\
\hline $\begin{array}{l}\text { Installed Equipment To Prevent Energy Wastage } \\
\text { And Leakages }\end{array}$ & 1 & 5 & 4.08 & 1.102 \\
\hline Installing more energy-efficient lighting system. & 1 & 5 & 4.54 & 1.051 \\
\hline $\begin{array}{l}\text { Save energy by switching off lights when there is } \\
\text { adequate natural light. }\end{array}$ & 1 & 5 & 3.44 & 1.015 \\
\hline $\begin{array}{l}\text { Switching off equipment, air conditioning and } \\
\text { computer when last to leave }\end{array}$ & 1 & 5 & 4.45 & 1.132 \\
\hline \multicolumn{5}{|l|}{ Waste Reduction and Recycling } \\
\hline Firm is aware of waste Management and recycling. & 1 & 5 & 4.50 & 1.201 \\
\hline $\begin{array}{l}\text { Employee awareness of waste management and } \\
\text { recycling. }\end{array}$ & 1 & 5 & 4.67 & 1.193 \\
\hline $\begin{array}{l}\text { Firm design for reducing waste and then reuse or } \\
\text { recycle as much as possible }\end{array}$ & 1 & 5 & 4.03 & 1.029 \\
\hline Firm providing waste management training to staff. & 1 & 5 & 4.14 & 1.118 \\
\hline $\begin{array}{l}\text { Adoption of ecological waste management and } \\
\text { disposal procedures }\end{array}$ & 1 & 5 & 4.54 & 1.205 \\
\hline
\end{tabular}


ecological activities reported mean values above 4.00, with the exception of "Replacing manual efforts with alternative mechanised operations," "Select processes that remove or reduce energy usage," and "Save energy by switching off lights when sufficient natural light." Some of the standard deviation values are slightly above 1.00 showed a very broad dispersion from the mean. "Employee awareness of waste management and recycling," "Applying environmental standards for purchasing decisions" and "Adoption of ecological waste management and disposal processes" for green purchasing and waste reduction and recycling proved to be strongly committed practises, with average values of 4.67, 4.56 and 4.55 , respectively. In the other hand, "Selecting processes that eliminate or reduce energy usage," "Saving energy by shutting off lights when there is ample natural light," and "Replacing manual activities with alternative mechanised operations" tend to be the least common method compared to the other practises found with their low mean values of 3.19, 3.44 and 3.90, respectively.

\subsection{Measurement Model}

The measurement model consists of the relationship between the latent variables and the measures (items) underlying each latent variable. Until continuing with the analysis of the study model for hypotheses testing, it is important to first determine the construct validity of the measurement model. Construct validity involves the degree to which the metrics represent their underlying structure (latent variables). Things in the measurement model need to show both convergent and discriminatory validity in order to establish construct validity. Convergent validity is characterised as the degree to which the measuring instrument objects compare with those in the measuring instrument that are designed to measure the same design (Mishra et al., 2019). In relation to convergent validity, discriminant validity can be checked for both reflective and formative constructs by checking whether "constructs are less than perfectly correlated" (Mackenzie et al., 2015). Discriminant validity includes the degree to which the measurements of the various constructs are different from each other and is measured by measuring the relationships between the constructs and the square root of the AVE for the construct (Fornell \& Larcker, 1981).

Establishing convergent validity requires satisfying the constraints based on the loading of metrics, the durability and the AVE. Table 5 lists the loading, reliability and AVE indications for all reflective items used in the model. The loading of all reflective indicators exceeded the minimum necessary cut-off standard of 0.60 . In terms of durability, the composite and Cronbach Alpha values for all reflective materials surpassed the threshold values of 0.70 suggested by Hair et al. (2010) and Nunnally (1978) respectively. For each construction, the AVE was above the recommended value of 0.50 proposed by Fornell and Larker (1981). In this analysis, environmental performance was considered to be a building block of formative indicators, as each indicator describes and defines exclusively the characteristics of sustainable ecological activities. Calculated 
Table 5. Showing reliability and validity for reflective indicators.

\begin{tabular}{|c|c|c|c|c|c|c|c|}
\hline $\begin{array}{l}\text { Latent Variables } \\
\text { (constructs) }\end{array}$ & Items of ecological practices & & Loading & $\alpha$ & AVE & CR & DV \\
\hline \multirow{4}{*}{$\begin{array}{l}\text { Green Purchasing } \\
\quad \text { (GP) }\end{array}$} & Apply environmental criteria when making purchasing decisions. & GP1 & 0.825 & \multirow{4}{*}{0.743} & \multirow{4}{*}{0.60921} & \multirow{4}{*}{0.86102} & \multirow{4}{*}{0.78052} \\
\hline & Eco-friendly packaging followed & GP2 & 0.768 & & & & \\
\hline & Preferred suppliers if ISO 14001 certification & GP3 & 0.68 & & & & \\
\hline & Purchase Green & GP4 & 0.84 & & & & \\
\hline \multirow{7}{*}{$\begin{array}{l}\text { Energy Efficiency } \\
\quad(\mathrm{EE})\end{array}$} & Replacing manual efforts with alternate mechanized operations. & EE1 & 0.762 & \multirow{7}{*}{0.851} & \multirow{7}{*}{0.64014} & \multirow{7}{*}{0.92523} & \multirow{7}{*}{0.80009} \\
\hline & Select processes that eliminate or reduce energy consumption & EE2 & 0.675 & & & & \\
\hline & Installing more energy-efficient lighting system & EE3 & 0.821 & & & & \\
\hline & $\begin{array}{l}\text { Save energy by switching off lights when there is adequate } \\
\text { natural light. }\end{array}$ & EE4 & 0.9 & & & & \\
\hline & $\begin{array}{l}\text { Switching off equipment, air conditioning and computer when } \\
\text { last to leave/not in use }\end{array}$ & EE5 & 0.813 & & & & \\
\hline & Install equipment to prevent energy wastage and leakages & EE6 & 0.793 & & & & \\
\hline & $\begin{array}{l}\text { Equipment installed to keep the energy consumption level at the } \\
\text { optimum }\end{array}$ & EE7 & 0.819 & & & & \\
\hline \multirow{5}{*}{$\begin{array}{c}\text { Waste Reduction } \\
\text { and Recycling } \\
\text { (WRR) }\end{array}$} & Firm is aware of waste Management and recycling. & WRR1 & 0.864 & \multirow{5}{*}{0.832} & \multirow{5}{*}{0.62731} & \multirow{5}{*}{0.89347} & \multirow{5}{*}{0.79203} \\
\hline & $\begin{array}{l}\text { Firm design for reducing waste and then reuse or recycle as } \\
\text { much as possible }\end{array}$ & WRR2 & 0.741 & & & & \\
\hline & Firm providing waste management training to staff & WRR3 & 0.762 & & & & \\
\hline & $\begin{array}{l}\text { Adoption of ecological waste management and disposal } \\
\text { procedures }\end{array}$ & WRR4 & 0.825 & & & & \\
\hline & $\begin{array}{l}\text { Employee awareness of waste management and recycling is at } \\
\text { expected level }\end{array}$ & WRR5 & 0.762 & & & & \\
\hline
\end{tabular}

AVE, CR and DV (Table 6) showing reliability and validity have been obtained in order to determine the indicator validity of this construct.

\subsection{Regression Analysis}

Regression analysis was adopted to examine the impact of ecological practices adoption on environmental performance and to test the $\mathrm{H} 1, \mathrm{H} 2$ and $\mathrm{H} 3$ hypotheses. In regression model, independent variables are the 3 constructs of ecological practices: Green Purchasing, Energy Efficiency and Waste reduction and recycling and environmental performance is the dependent variable. Regression analysis results are presented as follows: (Table 7).

In the above table, the environmental performance was regressed on ecological practices of GP, EE and WRR. The R-squared value is 0.514 . This implies that the research model clarifies $51.4 \%$ of the variance in environmental performance.

From the ANOVA Table 8, it can be observed that sig.value $=0.000$ and $p \leq$ 0.05 . There exists significant relationship between ecological practices and environmental performance. This means that there is a statistically significant difference 
Table 6. Showing reliability and validity for the formative indicators.

\begin{tabular}{|c|c|c|c|c|c|c|c|}
\hline Latent Variable & Items of Environmental Performance & & Loading & a & AVE & CR & DV \\
\hline \multirow{9}{*}{$\begin{array}{c}\text { Environmental } \\
\text { Performance (EP) }\end{array}$} & Reduction in wastages & EP1 & 0.669 & \multirow{9}{*}{0.923} & \multirow{9}{*}{0.5466} & \multirow{9}{*}{0.9292} & \multirow{9}{*}{0.7393} \\
\hline & Environmental regulation improves the growth of our company & $\mathrm{EP} 2$ & 0.759 & & & & \\
\hline & $\begin{array}{l}\text { Use of quality technology tools and quality management system } \\
\text { is not satisfactory }\end{array}$ & $\mathrm{EP} 3$ & 0.701 & & & & \\
\hline & Reduction in solid waste. & EP5 & 0.724 & & & & \\
\hline & Decrease in incidence of environmental accidents. & EP6 & 0.678 & & & & \\
\hline & Firm's environmental situations need to be improved & EP7 & 0.891 & & & & \\
\hline & Decrease in consumption for hazardous/harmful/toxic materials. & EP8 & 0.689 & & & & \\
\hline & No prevention steps to control pollution & EP10 & 0.693 & & & & \\
\hline & $\begin{array}{l}\text { Decrease in effluents, emission and solid waste by recycle and } \\
\text { reuse }\end{array}$ & EP11 & 0.673 & & & & \\
\hline
\end{tabular}

Table 7. Showing model summary.

\begin{tabular}{ccccc}
\hline \multicolumn{5}{c}{ Model Summary } \\
\hline Model & $\mathrm{R}$ & $\mathrm{R}$ Square & Adjusted R Square & Std. Error of the Estimate \\
\hline 1 & $0.7170^{\mathrm{a}}$ & 0.514 & 0.504 & 0.34900000 \\
\hline
\end{tabular}

aPredictors: (Constant), WRR, EE, GP.

Table 8. Showing ANOVA.

\begin{tabular}{ccccccc}
\hline \multicolumn{7}{c}{ NNOVA $^{\mathrm{a}}$} \\
\hline Model & Sum of Squares & df & Mean Square & F & Sig. \\
\hline & Regression & 50.388 & 3 & 16.796 & 40.570 & $0.000^{\mathrm{b}}$ \\
1 & Residual & 47.623 & 115 & 0.414 & & \\
& Total & 98.011 & 118 & & & \\
\hline
\end{tabular}

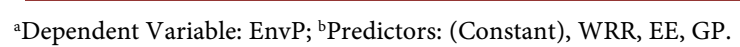

between means of different level of ecological practices and environmental performance in SMEs.

The test of $\mathrm{H} 1, \mathrm{H} 2$ and $\mathrm{H} 3$ evaluated whether GP, EE and WRR are positively related to environmental performance. The outcome $(\beta=0.426, t=4.900, p \leq$ $0.05)$ proposed that the relationship between GP and EnvP is significant and are positively connected with each other, and thus $\mathrm{H} 1$ is supported. Moreover, Table 9 shows the outcome of the significance test for the relationship between green purchasing and environmental performance. $\mathrm{H} 2$ is not supported by the ecological practices of energy efficiency $(\beta=0.097, \mathrm{t}=1.142, p \geq 0.05)$. As $p$-value is greater than 0.05 , were found to have positive and are insignificantly 
Table 9. Showing regression coefficient.

\begin{tabular}{|c|c|c|c|c|c|c|}
\hline \multicolumn{7}{|c|}{ Coefficients $^{\mathrm{a}}$} \\
\hline & \multirow{2}{*}{ Model } & \multicolumn{2}{|c|}{$\begin{array}{l}\text { Unstandardized } \\
\text { Coefficients }\end{array}$} & \multirow{2}{*}{$\begin{array}{c}\text { Standardized } \\
\text { Coefficients }\end{array}$} & \multirow[t]{2}{*}{$\mathrm{t}$} & \multirow{2}{*}{ Sig. } \\
\hline & & B & Std. Error & & & \\
\hline \multirow{4}{*}{1} & (Constant) & 5.133 & 1.374 & & 8.736 & 0.000 \\
\hline & GP & 0.426 & 0.049 & 0.240 & 4.900 & 0.000 \\
\hline & $\mathrm{EE}$ & 0.097 & 0.373 & 0.431 & 1.142 & 0.543 \\
\hline & WRR & 0.238 & 0.049 & 0.096 & 1.994 & 0.047 \\
\hline
\end{tabular}

aDependent Variable: EnvP.

related to ecological practices in selected SMEs. So, $\mathrm{H} 2$ is rejected in this study. $\mathrm{H} 3$ is suggested that waste reduction and recycling are positively connected with environmental performance. The results show that the relationship between WRR and EP is significant $(\beta=0.238, \mathrm{t}=1.994, p \leq 0.05)$. Thus, $\mathrm{H} 3$ is supported.

Table 9 gives the regression coefficient values. The R-squared value shows the measure of variance in the dependent variable, which can be clarified by the independent variable. In this case, the independent variables of ecological practices accounts for $51.4 \%$ of the variance in environmental performance. The ANOVA assisted to test the significance of the regression model. From Table 8, it can be understood that the sig. $p$ value $=0.000$. As $p<0.05$, the predictors are significantly better than expected. The regression line is predicted by the dependent variable. Next, Table 9 shows how the independent variables are associated to the dependent variable, as well as which variables are individually significant, independent of the dependent variable. The following regression equation can be framed, from the unstandardized coefficients B column:

Environmental Performance $=5.133+0.238 \mathrm{GP}+0.426 \mathrm{EE}+0.97 \mathrm{WRR}$

Data from the standardised beta coefficient column show the responsibility that an individual variable makes to the model. Moreover, the beta weight is the average amount that the dependent variable rises when the independent variable rises by one standard deviation. It is clear from Table 9 that the ecological practices of GP and WRR are significant with $p \leq 0.000$ can be accepted and EE is rejected. GP has the highest beta value and has the utmost impact on environmental performance. However, it might be seen from the outcome of the study, that the ecological practices of GP and WRR are significantly related with the development of environmental performance, except EE. Therefore, H1, H3 can be accepted and $\mathrm{H} 2$ is rejected. Figure 1 indicates the possible relationships between the independent variables (ecological practices) and dependent variable (economic performance), based on the hypotheses formulated and tested in this study. No significant impact exits between energy efficiency and environmental performance. 


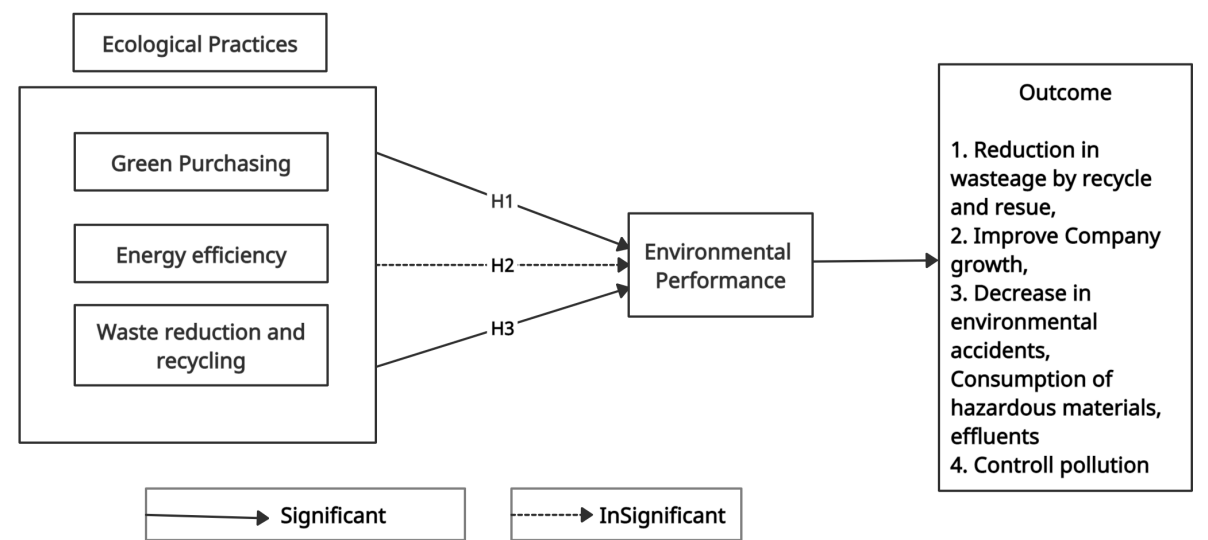

Figure 1. Showing possible relationship between ecological practices and environmental performance.

\section{Discussion}

The aim of this study was to investigate the effect of environmental practises on environmental performance in selected small and medium-sized manufacturing enterprises. The outcome showed that Green Purchasing was favourably affected and closely associated with environmental performance. Numerous research supports that green purchasing will minimize costs, improve productivity, remove waste and emissions, and create brand reputation (Duber-Smith, 2005). Min and Galle (2011) suggest that green purchasing is an environmentally-conscious sourcing method that eliminates waste sources and encourages the processing and reuse of bought products without negatively impacting the efficiency requirements of those materials. Past surveys have shown that changes in the manufacturing process and efficiency would increase the likelihood of improving environmental performance (Montabon et al., 2017). Consequently, strong encouragement from the top and middle management of the effort is still believed to have a high effect on the improvement of environmental practises. The findings of the current study also indicate that small and medium-sized businesses are persuaded that green purchasing will improve environmental efficiency among companies.

Energy efficiency findings show that there is no significant effect of energy efficiency on environmental performance. According to Bondoni (2012), energy management is interpreted as a wise and productive usage of energy, reducing prices, optimising revenues and enhancing the company's competitive position. The findings of the study showed that the development of small and medium-sized businesses had problems related to energy quality and consumption. Several surveys of small and medium-sized enterprises (SMEs) have shown that, considering the availability of cost-effective energy efficiency initiatives, investment in energy efficiency is always poor (Trianni et al., 2016). According to study, this poor implementation is due to the presence of multiple obstacles to energy production (Engelken et al., 2016). Choong et al. (2012) find that energy 
efficiency is important in their studies and acknowledges the economic and environmental advantages that energy production can offer to small and medium-sized businesses. However, several researchers (Sardianou, 2008) have observed that energy efficiency does not substantially impact ecological green practises. The emergence of such cases illustrates the shortcomings and detrimental impacts on small and medium-sized businesses in the adoption of sustainable ecological activities.

Finally, the findings of waste reduction and recycling demonstrate that there is a substantial connection between WRR and environmental performance. This may have stemmed from the fact that the majority of industrial SMEs became aware of the implementation of waste management programmes and procedures. However, for certain small and medium-sized owners/managers, a lack of knowledge of the hazards of waste has led to a negligible relationship and this situation is accentuated by the poor establishment of a waste management scheme and facilities (Terazono et.al, 2015). With the right assistance from the environmental protection system, an efficient waste management plan will be used to repay the investment (Stojanovic S. 7 steps in handling waste according to ISO 14001. 2016; Retrieved from Advisera:

https://advisera.com/14001academy/blog/2016/11/07/7-steps-inhandling-wasteaccording-to-iso-14001). The findings of this study reveal that 52.8 per cent of SMEs are ISO 14001 (EMS) approved, use waste management policies to satisfy ISO 14001 specifications. Based on the findings obtained, it can be inferred that EMS is an operational mechanism for handling and solving waste management problems and enhancing environmental efficiency. Around the same time, businesses are in a position to boost their overall efficiency rather than environmental performance alone.

\section{Conclusion}

In the recent world, a growing environmental understanding, the idea of green procurement, waste reduction and recycling and energy efficiency are closely related to environmental efficiency. There is a scarcity of empiric research to examine the nature of ecological activities. This research adds to the literature offering insight into the ecological activities embraced and their effect on the environmental efficiency of small and medium-sized manufacturing enterprises. The aim of this research is to research the impact of ecological activities on environmental performance in selected small and medium-sized manufacturing enterprises in Karnataka. The research results met the research goals and addressed the research questions in this study. The level of implementation of sustainable practises is moderate, as energy conservation does not have an impact on environmental performance. This poor implementation is due to the presence of multiple obstacles to energy production. The result shows that green purchasing and waste reduction and recycling are positively affected and highly associated with environmental performance. 


\section{Recommendations}

1) It is recommended that small and medium-sized companies (SMEs) should designate environmental managers listed under the Green Employment group to introduce environmental policies and integrate environmental protection, education and training programmes into their enterprises.

2) Awareness should be created among the SMEs on the adoption of Green Management practices, including the technology infrastructure used to recycle waste, purify water, generate renewable energy, and preserve natural resources to build a complementary range of environmental sustainability and incorporate green technology policy into their company's policy, since this is of value to businesses contemplating sustainable growth prospects.

3) In view of the strategic significance of this sector, it is crucial that its development be followed by responsible policy mechanisms for growth of business with environmental sustainability. The Ministry of Micro, Small and Medium Enterprises (MoMSME) launched an environmental management scheme named ZED (Zero Defect-Zero Effect) in India on 31 July 2017. The main concept is to encourage minimal waste and minimum environmental impact on small and medium-sized companies and to allow them to be part of the green initiative to improve India's exports. To empower entrepreneurs, the Government has also provided some incentives under this programme, e.g. Rs.25 Lakhs to set up a new Effluent Treatment Plant (ETP), a new Technology Plant, etc. Even the Government grants 50 percent loan concession and Rs. 10 Lakhs for registration and handholding of ZED.

\section{Limitations and Future Scope of Study}

Although this study reveals useful insights, it does have drawbacks that should drive further research. First, the majority of respondents were managers and few respondents were owners or co-owners; they may have different views of the effect of environmental activity adoption on environmental performance. Second, due to time limitations, the number of variables explored in this analysis is assumed to be limited to the discovery of other fundamental factors that would affect the implementation of ecological practises. Future studies are recommended to explore the impact of other ecological practises that inspire companies to take steps towards green practises that have not been explored in this report. In addition, future studies may replicate this study using larger populations and samples and different contexts, such as different sectors or regions. Finally, for future studies, it is proposed that the study may be extended to include more variables such as safety at work, customer satisfaction and the employee commitment to measure the performance of the organisation.

\section{Conflicts of Interest}

The authors declare no conflicts of interest regarding the publication of this paper. 


\section{References}

Agan, Y., Acar, M. F., \& Borodin, A. (2013). Drivers of Environmental Processes and Their Impact on Performance: A Study of Turkish SMEs. Journal of Cleaner Production, 51, 23-33. https://doi.org/10.1016/j.jclepro.2012.12.043

Bondoni, C. (2012). ISO 50001-Energy Management. Consequences of its Application, ABB Group.

Chardine-Baumann, E., \& Botta-Genoulaz, V. (2014). A Framework for Sustainable Performance Assessment of Supply Chain Management Practices, Computers and Industrial Engineering. Computers \& Industrial Engineering, 76, 138-147.

https://hal.archives-ouvertes.fr/hal-01356044

https://doi.org/10.1016/j.cie.2014.07.029

Chiou, T.-Y., Chan, H. K., Lettice, F., \& Chung, S. H. (2011). The Influence of Greening the Suppliers and Green Innovation on Environmental Performance and Competitive Advantage in Taiwan. Transportation Research Part E: Logistics and Transportation Review, 47, 822-836. https://econpapers.repec.org/article/eeetranse https://doi.org/10.1016/j.tre.2011.05.016

Choong, W. W., Chong, Y. F., Low, S. T., \& Mohammed, A. H. B. (2012). Implementation of Energy Management Key Practices in Malaysian Universities. International Journal of Emerging Sciences, 2, 455-477.

Cote, R., Booth, A., \& Louis, B. (2016). Eco-Efficiency and SMEs in Nova Scotia, Canada. Journal of Cleaner Production, 14, 542-550. https://doi.org/10.1016/j.jclepro.2005.07.004

Duber-Smith, D. C. (2005). The Green Imperative. Soap, Perfumery and Cosmetics. Journal of Industrial Engineering and Management, 78, 24-26.

Eltayeb, T. K., Zailani, S., \& Ramayah, T. (2011). Green Supply Chain Initiatives among Certified Companies in Malaysia and Environmental Sustainability: Investigating the Outcomes. Resources, Conservation \& Recycling, 55, 495-506.

https://doi.org/10.1016/j.resconrec.2010.09.003

Engelken, M., Römer, B., Drescher, M.,Welpe, I. M., \& Picot, A. (2016). Comparing Drivers, Barriers, and Opportunities of Business Models for Renewable Energies: A Review. Renewable and Sustainable Energy Reviews, 60, 795-809.

https://doi.org/10.1016/j.rser.2015.12.163

Fornell, C., \& Larcker, D. F. (1981). Evaluating Structural Equation Models with Unobservable Variables and Measurement Error. Journal of Marketing Research, 18, 39-50. https://www.jstor.org/stable/3151312 https://doi.org/10.1177/002224378101800104

Geng, R. Q., Afshin Mansouri, S., \& Aktas, E. (2017). The Relationship between Green Management Practices and Performance: A Meta-Analysis of Empirical Evidences in Asian Emerging Economies. International Journal of Production Economics, 183, 245-258. https://doi.org/10.1016/j.ijpe.2016.10.008

Ghazilla, R., Sakundarini, N., Abdul-Rashid, S., Ayub, N., Olugu, E., \& Musa, S. (2015). Drivers and Barriers Analysis for Green Manufacturing Practices in Malaysian SMEs: A Preliminary Findings. Procedia CIRP, 26, 658-663. https://doi.org/10.1016/j.procir.2015.02.085

Goyal, M. (2013). Future Outlook of Green Management Practices. Journal of Business Management, 14, 68-72. https://doi.org/10.9790/487X-1466872

Green Jr. K. W., Zelbst, P. J., Meacham, J., \& Bhadauria, V. S. (2012). Green Supply Chain 
Management Practices: Impact on Performance. Supply Chain Management. An International Journal, 17, 290-305. https://doi.org/10.1108/13598541211227126

Gu, B., Zhu, W., Wang, H., Zhang, R., Liu, M., Chen, Y., Wu, Y., Yang, X., He, S., Rong Cheng, R., Yang, J., \& Bi, J. (2014). Household Hazardous Waste Quantification, Characterization and Management in China's Cities: A Case Study of Suzhou. Waste Management, 34, 2414-2423. https://doi.org/10.1016/j.wasman.2014.06.002

Hair, Jr. J. F., Black, W.C., Babin, B. J., \& Anderson, R. E. (2010). Multivariate Data Analysis: A Global Perspective (7th ed.). Pearson Education.

Laosirihongthong, T., Adebanjo, D., \& Choon Tan, K. (2013). Green Supply Chain Management Practices and Performance. Industrial Management \& Data Systems, 113, 1088-1109. https://doi.org/10.1108/IMDS-04-2013-0164

Lee, V.-H., Ooi, K.-B., Chong, A.Y.-L., \& Lin, B. (2015). A Structural Analysis of Greening the Supplier, Environmental Performance and Competitive Advantage. Production Planning \& Control, 26, 116-130. https://doi.org/10.1080/09537287.2013.859324

Lepoutre, J. \& Heene, A. (2016). Investigating the Impact of Firm Size on Small Business Social Responsibility: A Critical Review. Journal of Business Ethics, 67, 257-273.

http://hdl.handle.net/10.1007/s10551-006-9183-5

https://doi.org/10.1007/s10551-006-9183-5

Lu, J. W., Chang, N. B., \& Liao, L. (2013). Environmental Informatics for Solid and Hazardous Waste Management: Advances, Challenges, and Perspectives. Critical Reviews in Environmental Science and Technology, 43, 1557-1656. https://doi.org/10.1080/10643389.2012.671097

Mackenzie, S. B., Podsakoff, P. M., \& Jarvis, C. B. (2015). The Problem of Measurement Model Misspecification in Behavioural and Organizational Research and Some Recommended Solutions. The Journal of Applied Psychology, 90, 710-730. https://doi.org/10.1037/0021-9010.90.4.710

Min, H., \& Galle, W. P. (2011). Green Purchasing Practices of US Firms. International Journal of Production and Operations Management, 21, 1222-1238. https://doi.org/10.1108/EUM0000000005923

Mishra, M. K., Choudhury, D., \& Rao, K. S. V. G. (2019). Impact of SMEs Green Supply chain Practice Adoption on SMEs Firm and Environmental Performance. Theoretical Economics Letters, 9, 1901-1919. https://doi.org/10.4236/tel.2019.96121

Montabon, F., Sroufe, R., \& Narasimhan, R. (2017). An Examination of Corporate Reporting, Environmental Management Practices and Firm Performance. Journal of Operations Management, 25, 998-1014. https://doi.org/10.1016/j.jom.2006.10.003

Murali Krishna, K. V. S. G. (2015). Air Pollution and Control (p. 307). Kaushal \& Co.

Nunnally, J. (1978). Psychometric Theory(2nd ed.). McGraw Hill.

Paula, I. D., Bholeb, G. P., \& Chaudharic, J. R. (2014). A Review on Green Manufacturing: It's Important, Methodology and Its Application. Procedia Materials Science, 6, 1644-1649. https://doi.org/10.1016/j.mspro.2014.07.149

Peter, Y., Mathivannan, J., Lee, E. K., Suresh, N., Yee, C. F., \& Mohamad, F. (2017). Green Initiatives Adoption: Perspective of E \& E Manufacturing SMEs Sustainability. International Journal of Economic Research, 14, 359-375.

Pradip, K. D. (2016). An Introduction to the Concept of Environmental Management: Indian Context. International Journal of Innovation and Economic Development, 2, 25-34. https://doi.org/10.18775/ijied.1849-7551-7020.2015.24.2003

Sardianou, E. (2008). Barriers to Industrial Energy Efficiency Investments in Greece. 
Journal of Cleaner Production, 16, 1416-1423. https://doi.org/10.1016/j.jclepro.2007.08.002

Seema, U., Rauf, I., Anju, S., \& Prajakta, M. (2016). A Critical Study of Environmental Control Technologies and Practices in Small and Medium Enterprises in India. International Proceedings of Chemical, Biological and Environmental Engineering, 91, 95-102.

Shivani, S., \& Jain, V. K. (2017). Impact of Green Management Practices on Organizational Performance: A Review. Asia Pacific Journal of Research, 1, 104-109.

Terazono, A., Moriguchi, Y., Yamamoto, Y. S., Sakai, S.-I., Inanc, B., Yang, J., \& Mungcharoen, T. (2015). Waste Management and Recycling in Asia. International Review for Environmental Strategies, 5, 477-498.

Trianni, A., Cagno, E., \& Farné, S. (2016). Barriers, Drivers and Decision-Making Process for Industrial Energy Efficiency: A Broad Study among Manufacturing Small and Medium-Sized Enterprises. Applied Energy, 162, 1537-1551.

https://doi.org/10.1016/j.apenergy.2015.02.078

Tseng, M., Chiu, A., Lin, Y., \& Chinag, J. (2016). The Relationship of Continuous Improvement and Cleaner Production on Operational Performance: An Empirical Study in Electronic Manufacturing Firms, Taiwan China. International Journal of Management Science and Engineering Management, 1, 71-80.

https://doi.org/10.1080/17509653.2006.10670999

Vernon, J., Essex, S., Pinder, D., \& Curry, K. (2013). The “Greening” of Tourism Micro-Businesses: Outcomes of Focus Group Investigations in South East Cornwall. Business Strategy and the Environment, 12, 49-69. https://doi.org/10.1002/bse.348

Zhu, Q., Sarkis, J., \& Lai, K. H. (2007). Green Supply Chain Management: Pressures, Practices and Performance within the Chinese Automobile Industry. Journal of Cleaner Production, 15, 1041-1052. http://hdl.handle.net/10397/34072 https://doi.org/10.1016/j.jclepro.2006.05.021

\section{Abbreviations List}

SMEs $=$ Small and Medium Enterprises

SPSS $=$ Statistic Product and Service Solutions

AVE $=$ Average Variance Extracted

MoMSME = Ministry of Micro, Small and Medium Enterprises

$\mathrm{ZED}=$ Zero Defect-Zero Effect

$\mathrm{ETP}=$ Effluent Treatment Plant 